\title{
PURIFICATION AND MOLECULAR WEIGHT DETERMINATION OF KERATINASE ISOLATED FROM STREPTOMYCES MALAYSIENSIS
}

\author{
M. PAVANI ${ }^{*}$, G. GIRIJASANKAR ${ }^{2}$, K. MALLIKA ${ }^{3}$, G. VIDHYA SAGAR ${ }^{4}$ \\ ${ }^{1}$ Srinivasarao College of Pharmacy, Visakhapatnam, ${ }^{2}$ Andhra University, Visakhapatnam, ${ }^{3}$ M. Pharm, Andhra University, \\ Visakhapatnam, ${ }^{4}$ Srinivasarao College of Pharmacy, Visakhapatnam \\ Email: kommoju.pavani@gmail.com
}

Received: 19 Jul 2017 Revised and Accepted: 21 Sep 2017

\section{ABSTRACT}

Objective: The aim of the present study was to purify and determine the molecular weight of keratinase isolated from Streptomyces malaysiensis.

Methods: For that purpose purification was done using ammonium sulphate and Sephadex-LH 100 column chromatography. Further, the fractions were pooled and subjected to molecular weight determination using sodium dodecyl sulphate-polyacrylamide gel electrophoresis (SDS-PAGE).

Results: The obtained results showed keratinase with $47.57 \%$ recovery, 3.5 -fold purification and an estimated molecular mass of 27,000 Da. Keratinase showed an optimal activity at $60^{\circ} \mathrm{C}$ and $\mathrm{pH}$ 8. Keratinase activity of the purified product was assayed with feather powder as a substrate. The isolated strain was identified as Streptomyces malaysiensis based on phylogenetic tree analysis. The strain isolated from termite mound soil showed the highest keratinase activity, which could be considered a microorganism of environmental origin.

Conclusion: The production of keratinase on simple media with feathers as sole source allowing its production from the cheap substrate and a commercial production with low production cost. Stability in the presence of detergents, surfactants and solvents make this keratinase extremely useful for a biotechnological process involving keratin.

Keywords: Streptomyces, Keratinase, Purification, Feather powder, Environment protection

(C) 2017 The Authors. Published by Innovare Academic Sciences Pvt Ltd. This is an open-access article under the CC BY license (http://creativecommons.org/licenses/by/4.0/) DOI: http://dx.doi.org/10.22159/ijpps.2017v9i11.21442

\section{INTRODUCTION}

Microbial keratinases have become biotechnologically important since they target the hydrolysis of highly rigid, strongly cross-linked structural polypeptide "keratin". These enzymes are largely produced in the presence of keratinous substrates in the form of hair, feather, wool, nail, horn etc. during their degradation. The complex mechanism of keratinloysis involves the cooperative action of sulfitolytic and proteolytic systems. Keratinases are robust enzymes with a wide temperature and $\mathrm{pH}$ activity.

The keratinous wastes largely comprise of insoluble structural protein "keratin". It is increasingly accumulating in the environment mainly from various industries. Today, it is also becoming a part of solid waste management since it is tough to degrade due to the highly rigid structure rendered by extensive disulphide bonds and cross-linkage. Hence, there is a demand for developing biotechnological alternatives for recycling of such wastes.

Keratin forms a major component of the epidermis and its appendages viz. hair, feather, nails, horns hoofs scales and wool. Keratins are also grouped into hard and soft keratins according to the sulfur content. Hard keratins found in appendages like feathers, hair, hoofs and nails have high disulphide bond content and are tough and inextensible. Whereas, soft keratins like skin and callus have a low content of disulfide bonds and are more pliable $[1,2]$. The intensive cross-linkage in keratins hinders their degradation by commonly known proteolytic enzymes like trypsin, pepsin and papain [3]. Keratinases (EC 3.4.21/2499.11) are by and large serine or metalloproteases capable of degrading the structure forming keratinous proteins. Since most of the purified keratinases known to date cannot completely solubilize native keratin $[4,5]$, their exact nature and uniqueness for keratinolysis is still an enigma in the world of proteases. Although keratinases from dematophytic fungi have long been well known due to their notorious pathogenic nature [6] these enzymes have only recently gained biotechnological impetus. Their growing importance is mainly contributed to the isolation of keratinases from non-pathogenic microorganisms and their ability to degrade the tough insoluble keratin of feather and convert it into economically useful feather meal [7-9], nitrogenous fertilizers, biodegradable films, glues and foils $[10,11]$.

In the present study, we report an efficient method for the purification and molecular weight determination of keratinase from Streptomyces malaysiensis.

\section{MATERIALS AND METHODS}

Chemicals and reagents

All chemicals and reagents used in the present study are procured from "Sigma-Aldrich".

\section{Collection of samples}

In the present study, samples were collected in sterile containers from different sites of termite mound soils in and around Visakhapatnam, Andhra Pradesh, India. From these samples, actinomycetes were isolated and screened for keratinolytic activity, followed by extraction of the bioactive compound.

\section{Isolation of actinomycetes}

About $1 \mathrm{~g}$ of termite mound soil was taken and transferred to a sterile conical flask each containing $50 \mathrm{ml}$ of sterile water, mixed well and then placed on a rotary shaker at $150 \mathrm{rpm}$ for $30 \mathrm{~min}$. Serial dilutions were made from this solution upto $10^{-10}$ order dilution after $30 \mathrm{~min}$.

One $\mathrm{ml}$ of each dilution was added to $49 \mathrm{ml}$ of sterile casein agar medium containing rifampicin $(25 \mu \mathrm{g} / \mathrm{ml}$ medium $)$ and cycloheximide $(50 \mu \mathrm{g} / \mathrm{ml}$ medium $)$ to inhibit the growth of bacteria and fungi respectively and poured into sterile Petri plates aseptically and kept for solidification. After solidification plates were incubated for the growth of actinomycetes colonies at $28^{\circ} \mathrm{C}$ for $7 \mathrm{~d}$ [12].

\section{Preliminary screening}

The proteolytic activity of the actinomycetes isolates was determined by casein hydrolysis by Skim milk agar medium. Skim 
milk agar method was employed for primary screening of isolates. It is the rapid and simple procedure for detecting the proteolytic activity of the isolate. To $45 \mathrm{ml}$ of sterile milk agar base (Pancreatic digest of casein-0.5; Yeast extract-0.25; Glucose-0.1; Agar-2.0; distilled water up to-100; pH-7.0 \pm 0.2 ), $5 \mathrm{ml}$ of sterile skim milk was added aseptically, mixed well and poured into sterile Petri plates and was allowed to solidify for about $20 \mathrm{~min}$. After solidification of the medium, all actinomycetes isolates were streaked individually as a single straight line in the centre of Petri plate and incubated at 28 ${ }^{\circ}$ Cfor 5-7 d and observed for caseinolytic activity of the isolates [13].

\section{Secondary screening}

The promising isolates which showed caseinolytic activity obtained by primary screening was selected for secondary screening by shake flask studies. These selected isolates were subjected to shake flask fermentation experiment studies.

All the promising isolates were subjected to keratinase production by shake flask fermentation studies using the following modified medium in $(\% \mathrm{w} / \mathrm{v})\left(\mathrm{NH}_{4} \mathrm{Cl} 0.05, \mathrm{CaCO}_{3} 0.022, \mathrm{MgSO}_{4} .7 \mathrm{H}_{2} \mathrm{O} 0.02, \mathrm{~K}_{2} \mathrm{HPO}_{4} 0.03\right.$, yeast-extract 1.0 , sodium chloride 0.05 , ferrous sulphate 0.001 chicken feather 2, $\mathrm{pH} 7.5 \pm 0.2$ ) for their keratinolytic activity [14].

\section{Enzymatic assay of keratinase}

About $20 \mathrm{mg}$ of chicken feather powder was suspended in $4 \mathrm{ml}$ of $0.05 \mathrm{M}$ glycine/ $\mathrm{NaOH}$ buffer $\mathrm{pH} 10.09$ to which $1 \mathrm{ml}$ of culture filtrate was added. The reaction mixture was incubated at $60^{\circ} \mathrm{C}$ for $1 \mathrm{hr}$. After incubation, the reaction was terminated by adding $4 \mathrm{ml}$ of $5 \%$ trichloroacetic acid. The feather and insoluble residue were removed by filtration and the filtrate was centrifuged at $3000 \mathrm{rpm}$ for $5 \mathrm{~min}$. Proteolytic products in the supernatant were determined by reading the absorbance at $280 \mathrm{~nm}$. A control sample was prepared by adding TCA to the reaction mixture before incubation [15].

(Unit definition: One unit of keratinase activity was defined as the amount of enzyme required to produce an absorbance increase of 0.01 under the described assay conditions)

\section{Confirmation of keratinase activity}

The medium was prepared, supplemented with $2 \%$ chicken feather and autoclaved. $20 \mathrm{ml}$ of medium was then poured per plate and allowed to solidify. A loopful of culture growth was streaked on the centre of agar plates. After inoculation, the plates were incubated at $28{ }^{\circ} \mathrm{C}$ for $5 \mathrm{~d}$. Regions of enzyme activity were detected as clear areas, indicating that the hydrolysis of the substrate had occurred.

\section{Extraction of crude enzyme}

A trial was run to determine the optimal concentration required for the precipitation of enzyme with various concentrations of ammonium sulphate. For this purpose, a portion of the supernatant obtained after centrifugation was subjected to ammonium sulphate precipitation. Ammonium sulphate was added at different concentrations ranging from $20-80 \%$ saturation. The precipitates so obtained were suspended in $50 \mathrm{mmol}$ glycine/ $\mathrm{NaOH}$ buffer $\mathrm{pH} 10.0$ and tested for keratinase enzyme activity. The salting out the concentration of crude enzyme was established to be $80 \%$ on the basis of enzyme activity. 4.0 grams of crude precipitate so formed was separated by centrifugation for $15 \mathrm{~min}$, dialyzed against $1 \mathrm{~L}$ of $1.0 \mathrm{M}$ Tris buffer ( $\mathrm{pH} \mathrm{8.0)}$ for $20 \mathrm{~h}$. After dialysis, the solution was centrifuged. The precipitate formed during dialysis was removed after centrifugation and was discarded. For the present study, dialysis membrane-100 (Hi-Media) was used. The supernatant obtained after centrifugation was subjected to Sephadex LH-100 column chromatography that was pre-equilibrated with $10 \mathrm{mmol}$ Tris buffer ( $\mathrm{pH}$ 8.5). Fractions showing keratinase activity were pooled and concentrated by lyophilization.

\section{Sephadex-LH-100 chromatography}

The proper dialyzed solution was applied to a column of Sephadex-LH100 (Pharmacia, Sweden). It was then equilibrated with $10 \mathrm{mmol}$ Tris $\mathrm{HCl}$ buffer, with a $\mathrm{pH}$ of 8.5. Subsequently, the column was eluted with a gradient of $0-1.0 \mathrm{M} \mathrm{NaCl}$ in $10 \mathrm{mmol}$ Tris $\mathrm{HCl}$ buffer with a $\mathrm{pH}$ of 8.5 , after which $3 \mathrm{ml}$ fractions were collected at a flow rate of $0.5 \mathrm{ml} / \mathrm{min}$.
Fractions with enzyme activity were pooled, dialyzed against distilled water, freeze-dried, and stored at $-20^{\circ} \mathrm{C}$ until use [16].

Sodium dodecyl sulphate-polyacrylamide gel electrophoresis (SDS-PAGE)

Sephadex LH-100 column chromatography fractions showing enzymatic activity were pooled, lyophilized and then subjected to SDS-PAGE. It was performed according to Laemmli (1970) using $12 \%$ acrylamide [17].

\section{Molecular identification of the isolate}

Molecular identification and characterization of the isolate TMS1a was carried out by $16 \mathrm{~S}$ rRNA gene sequencing analysis of Streptomyces taxonomy to investigate the relationships at genus, species and strain level. This was performed at Institute of Microbial Technology (IMTECH), Chandigarh. Evolutionary history and evolutionary distances were inferred by using Neighbor-Joining method (Saitou and Nei, 1987) and Kimura 2-parameter method (Kimura, 1980) [18, 19].

\section{RESULTS}

\section{Screening and isolation of actinomycetes}

Soil samples were collected from termite mounds at different places in Visakhapatnam, Andhra Pradesh and named as TMS. A total of 50 colonies were isolated from the soil samples by serial dilution method. Based on the color of the colony, the pigment of the colony and aerial mycelium, similar colonies were pooled together and 32 colonies were selected and identified as actinomycetes as shown in fig. 1.

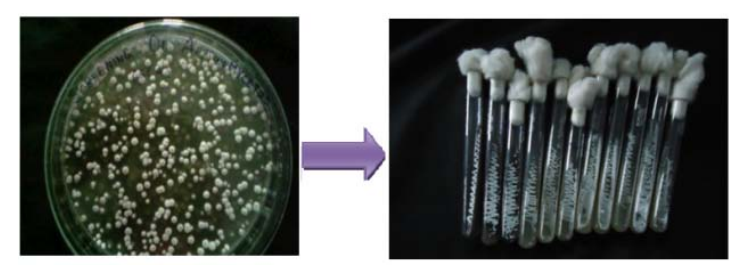

Fig. 1: Screening and isolation of actinomycetes

\section{Preliminary screening (casein hydrolysis)}

Proteolytic activity was studied with milk casein agar medium. The protease activity of the isolate was determined by the appearance of the zone of clearance on the plate. All the 32 actinomycete isolates which were isolated were subjected to primary screening by casein hydrolysis. Out of 32 isolates, 10 isolates showed clear zone around the growth of the isolates.

\section{Secondary screening (Keratinase assay)}

Keratinolytic activity was determined for all 10 isolates. It was found that the range of keratinase production was from $3.5-20.5 \mathrm{IU} / \mathrm{ml}$. Out of the 10 isolates, TMS $1 \mathrm{a}(20.5 \mathrm{IU} / \mathrm{ml})$ showed high keratinase activity as shown in table 1 . Hence this isolate was selected for further studies.

\section{Testing on keratin agar plates}

The isolates TMS1a exhibited keratinolytic activity by hydrolyzing keratin on keratin agar plates. A Clear zone of hydrolysis was observed around the growth TMS1a isolate as shown in the fig. 2 .

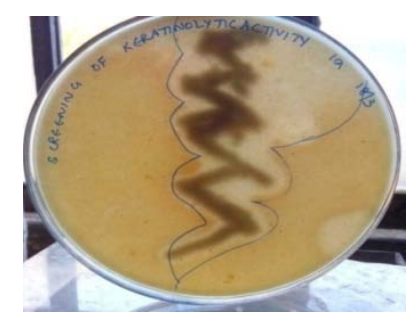

Fig. 2: Keratinolyic activity by isolate TMS 1a on keratin agar plates 
Table 1: Production of keratinase by various isolates from termite mound soil (TMS)

\begin{tabular}{lll}
\hline S. No. & Isolate & Keratinase activity $(\mathbf{I U} / \mathbf{m l})$ \\
\hline 1. & TMS1a & $20.5 \pm 0.5$ \\
2. & TMS2a & $16.0 \pm 1.0$ \\
3. & TMS3a & $5.5 \pm 0.5$ \\
4. & TMS4a & $14.5 \pm 0.5$ \\
5. & TMS5a & $3.5 \pm 0.5$ \\
6. & TMS6a & $14.0 \pm 1.0$ \\
7. & TMS7a & $1.5 \pm 0.5$ \\
8. & TMS8a & $5.8 \pm 0.7$ \\
9. & TMS9a & $4.0 \pm 1.0$ \\
10. & TMS10a & $3.5 \pm 0.5$ \\
\hline
\end{tabular}

TMS1a $20,20.5,21=20.5 \pm 0.5$, TMS2a 17,16,15 $=16.0 \pm 1.0$, TMS3a 6,5,5.5 $=5.5 \pm 0.5$, TMS4a $15,14,14.5=14 \pm 0.5$, TMS5a $4,3,3.5=3.5 \pm 0.5$, TMS6a $13,14,15=14.0 \pm 1.0$, TMS7a $2,1,1.5=1.5 \pm 0.5$, TMS8a $6,5,6.5=5.8 \pm 0.7$, TMS9a $5,4,3=4.0 \pm 1.0$, TMS10a $4,3,3.5=3.5 \pm 0.5$.

\section{Purification through DEAE-Sephadex-LH chromatography}

The proteins from the crude enzyme extract were precipitated by the ammonium sulphate $(80 \%)$ precipitation and most of the enzyme activity was retained in the precipitate. The specific activity of the enzyme increased to 46 and $70 \mathrm{IU} / \mathrm{mg}$ after dialysis and Sephadex LH-100 column chromatography respectively. The purity of keratinase increased by 3.5 folds with $47.57 \%$ recovery in Sephadex LH-100 purification step. The purification steps for keratinase were summarized in table 2.

Table 2: Purification of keratinase from the strain TMS1a

\begin{tabular}{|c|c|c|c|c|c|}
\hline Purification steps & Total activity (IU) & Total protein (mg) & Specific activity (IU/mg) & Purification fold & Yield (\%) \\
\hline Fermented broth & 206 & 10.3 & 20 & 1.0 & 100 \\
\hline Ammonium sulphate precipitation & 112 & 3.5 & 32 & 1.6 & 54.36 \\
\hline Dialysis & 119.6 & 2.6 & 46 & 2.3 & 58.05 \\
\hline Sephadex LH-100 chromatography & 98 & 1.4 & 70 & 3.5 & 47.57 \\
\hline
\end{tabular}

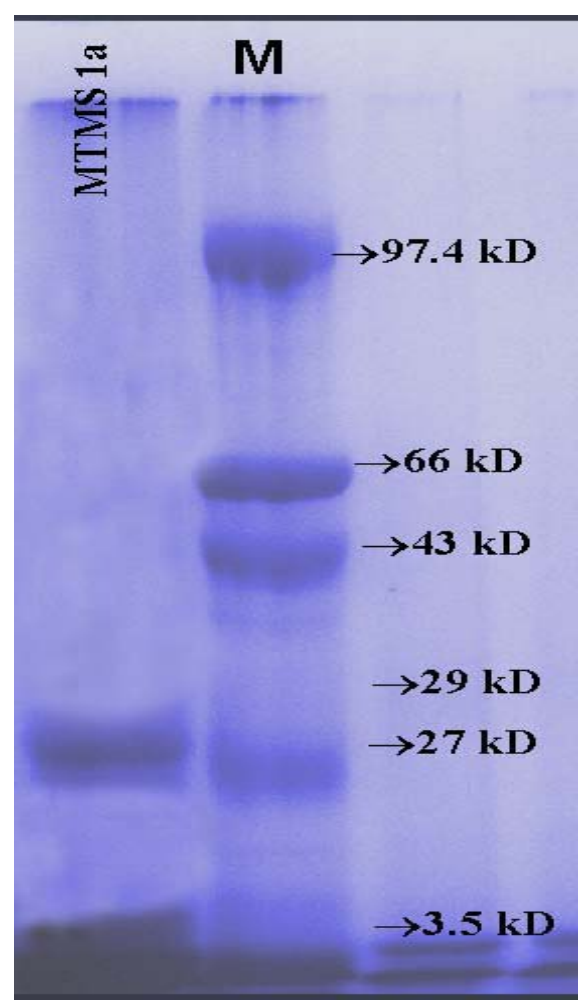

Fig. 3: Sodium dodecyl sulphate-polyacrylamide gel electrophoresis (SDS-PAGE) image of purified enzyme from the isolate TMS 1a, M indicates: Standard protein marker 3.5, 27, 29, 43, 66, 97.4 kDa

Sodium dodecyl sulphate-polyacrylamide gel electrophoresis (SDS-PAGE)

Specifically, the purified enzyme was analyzed by polyacrylamide gel electrophoresis, and a unique protein band was visualized after ion exchange chromatography. The enzyme in the SDS-PAGE showed a molecular weight of approximately $27 \mathrm{kDa}$ as shown in fig. 3.

\section{Phylogenetic tree analysis}

The evolutionary history was inferred using the Neighbor-Joining method (Saitou and Nei, 1987). The tree is drawn to scale, with branch lengths in the same units as those of the evolutionary distances used to infer the phylogenetic tree. The evolutionary distances were computed using the Kimura 2-parameter method 
(Kimura, 1980) and are in the units of the number of base substitutions per site. The rate variation among sites was modelled with a gamma distribution (shape parameter $=1$ ). The isolate
MTMS1a showed 100\% homology to Streptomyces malaysiensis. Genebank accession number for all the type strains considered in the analysis are shown in the bracket as shown in fig. 4.

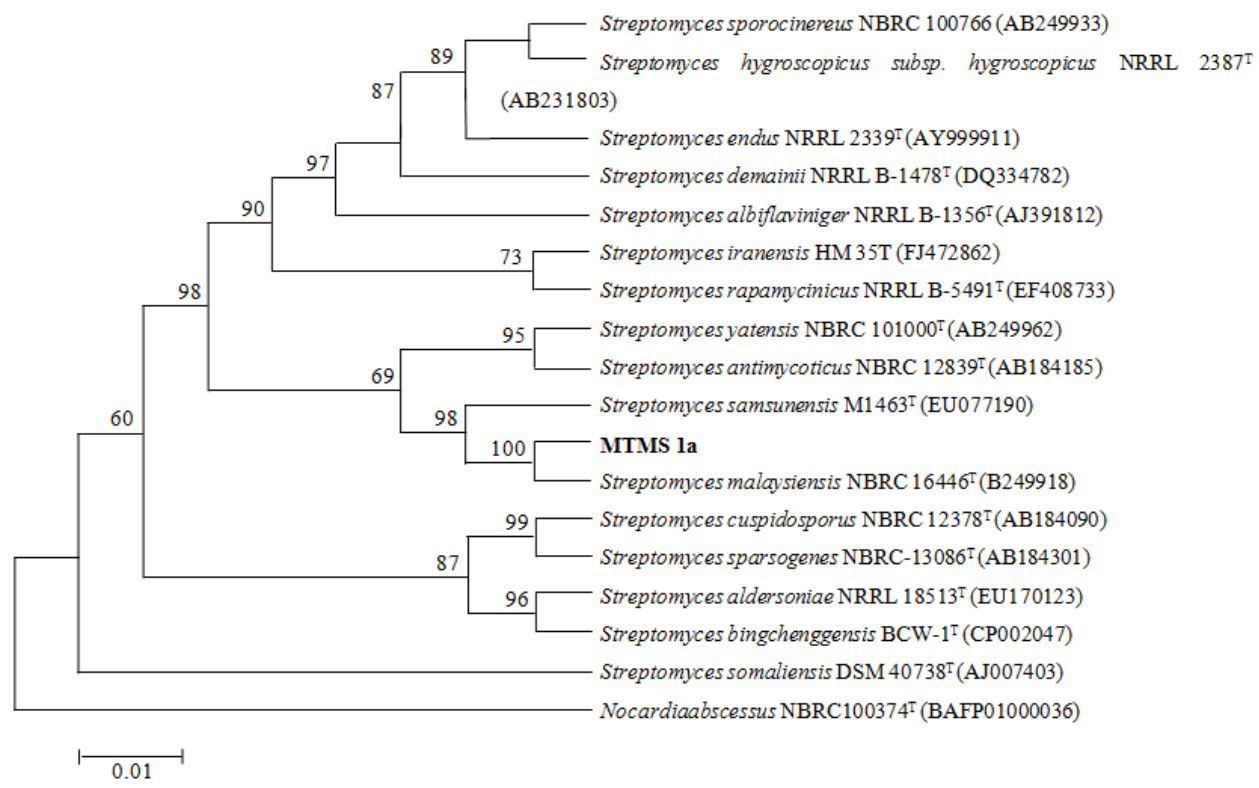

Fig. 4: Neighbour-joining phylogenetic tree of strain TMS 1a made by IMTECH

\section{DISCUSSION}

Keratinases from micro-organisms have attracted a great deal of attention in the last decades. In our investigation, we describe our keratinolytic S. malaysiensis (TMS1a) able to degrade chicken feather using keratin as substrate. This suggests its potential use in biotechnological processes involving environmental protection. Actinomycetes colonies were recognized by their characteristic tough leathery colonies that adhered to agar surface, branched vegetative mycelia and when present, aerial mycelia and spore formation. Smriti et al., (2012) reported similar work of actinomycetes from poultry waste [20]. Of the different media employed for isolation and estimation of actinomycetes population, starch casein agar medium provided better recovery of actinomycetes. This medium has starch as the complex carbohydrate source and casein as a nitrogen source. A similar finding was reported by different investigators (Kuster and Williams, 1964; Ellaiah et al., 2004; Sujatha and Swethalatha, 2017) [21-23].

Proteins are made up of various amino acids linked together in long chains by means of peptide bonds. Many microorganisms can hydrolyze a variety of proteins into peptides (short chains of amino acids) and eventually into individual amino acids. They can then use these amino acids to synthesize their own proteins and other cellular molecules or to obtain energy. In the present study, the objective of the primary screening is to isolate protease producing actinomycetes based on the proteolytic activity of the isolates. As keratinase is one type of protease enzyme. As casein hydrolysis is only an indication of protease production. Secondary screening was performed for the keratinolytic activity of the isolates. Keratinolytic activity was determined for all 10 isolates. Out of the 10 isolates, MTMS 1a $(20.0 \mathrm{IU} / \mathrm{ml})$ showed high keratinase activity. Hence this isolate was selected for further studies. Similar results were found for extracellular keratinase by Streptomyces fradiae (Noval and Nickerson, 1959), Bacillus halodurans (Prakash et al., 2010) and keratinolytic metalloprotease by Chryseobacterium sp. kr6 (Riffel et al., 2007) [24-26].

According to Singh, the keratinase producing organisnm (Nocardiopsis sp.) showed antimicrobial and anticancer activities. From this the future prospect of our work is anticancer activity [27].
Keratinases have become biotechnologically important since they target the hydrolysis of highly rigid, strongly cross-linked structural polypeptide "keratin". Hence the actinomycete isolate MTMS1a which has exhibited positive result in secondary screening (keratinase assay) was further confirmed for keratinase activity by streaking on keratinase agar plates [28].

\section{CONCLUSION}

A novel Streptomyces malaysiensis isolate producing keratinase was isolated and purified. The production of keratinase on simple media with feathers as sole source allowing its production from the cheap substrate and a commercial production with low production cost. Further work is focused on the application of pure keratinase on the keratinous tissue to identify the keratinolytic activity.

\section{AUTHORS CONTRIBUTION}

Meetakoti Pavani and Karri Mallika carried out the work presented in the manuscript. Meetakoti Pavani wrote the manuscript. Prof. G. Girijasankar and Prof. G. Vidhya Sagar contributed in its correction.

\section{CONFLICT OF INTERESTS}

The authors declare that they have no conflict of interest

\section{REFERENCES}

1. Voet D, Voet JG. Three dimensional structures of proteins. In: Stiefel J. ed Biochemistry. $2^{\text {nd }}$ edition. Wiley: NewYork; 1995. p. 154-6.

2. Schrooyen PMM, Dijkstra PJ, Oberthur RC, Bantjes A, Feijen J. Partially carboxymethylated feather keratins 2 . Thermal and mechanical properties of films. J Agric Food Chem 2001;49:221-30.

3. Papadopoulos MC. The effect of enzymatic treatment on amino acid content and nitrogen characteristics of feather meal. Anim Feed Sci Technol 1986;16:151-6.

4. Ignatova Z, Gousterova A, Spassov G, Nedkov P. Isolation and partial characterization of extracellular keratinase from wool degrading thermophilic actinomycetes strain Thermoactinomyces candidus. Can J Microbiol 1999;45:217-22.

5. Ramnani P, Singh R, Gupta R. Keratinolytic potential of Bacillus licheniformis RG1: structural and biochemical mechanism of feather degradation. Can J Microbiol 2005;51:191-6. 
6. Sohnle PG, Wagner DK. Fungal infections, cutaneous. In: J Lederberg. ed. Encyclopedia of microbiology. $2^{\text {nd }}$ edition. San Diego Academic; 2000. p. 451-9.

7. Onifade AA, A1-Sane NA, AI-Musallam AA, Al-Zarban S. A review: potentials for biotechnological applications of keratin degrading microorganisms and their enzymes for nutritional improvement of feathers and other keratins as livestock free resources. Bioresour Technol 1998;66:1-11.

8. Lin X, Inglis GD, Yanke LJ, Cheng KJ. Selection and characterization of the feather-degrading bacterium from conola meal compost. J Ind Microbiol Biotechnol 1999;23:149-53.

9. Riffel A, Lucas F, Heeb P, Brandelli A. Characterization of a new keratinolytic bacterium that completely degrades native feather keratin. Arch Microbiol 2003;179:258-65.

10. Friedrich AB, Antranikian G. Keratin degradation by Fervidobacterium pennavorans, a novel thermophilic anaerobic species of the order thermotogales. Appl Environ Microbiol 1996;62:2875-82.

11. De Toni CH, Richter MF, Chagas JR, Henriques JAP, Termignoni C. Purification and characterization of an alkaline serine endopeptidase from a feather-degrading Xanthomonas maltophila strain. Can J Microbiol 2002;48:342-8.

12. Ellaiah P, Ramana T, Bapi Raju KVVSN, Sujatha P, Uma sankar A. Investigations on marine actinomycetes from the Bay of Bengal near kakinada coast of Andhra Pradesh. Asian J Microbiol Biotechnol Environ Sci 2004;6:53-6.

13. Zerdani I, Faid M, Malik A. Feather wastes digestion by newly isolated strain Bacillus sp. In Morocco. Afr J Biotechnol 2004;3:67-70.

14. Bockle B, Galunski B, Muller R. Characterization of a keratinolytic serine protease from Streptomyces pactum DSM40530. Appl Environ Microbiol 1995;61:3705-10.

15. Dozie INS, Okeke CN, Unaeze NC. A thermostable, alkalineactive, keratinolytic proteinase from Chrysosporium keratinophilum. World J Microbiol Biotechnol 1994;10:563-7.

16. Jayalakshmi T, Krishnamoorthy P, Ramesh kumar G, Sivamani $P$. Purification and characterization of the keratinase enzyme from Streptomyces species JRS 19. New York Sci J 2011;4:59-67.
17. Laemmli UK. Cleavage of structural proteins during the assembly of the head of bacteriophage T4. Nature 1970;227:680-5.

18. Saitou N, Nei M. The neighbour-joining method: a new method for reconstructing phylogenetic trees. Mol Biol Evol 1987;4:406-25.

19. Kimura M. A sample method for estimating the evolutionary rate of base substitutions through comparative studies of nucleotide sequences. J Mol Evol 1980;16:111-20.

20. Smriti S, Anju Rawat S, Abhinav G, Anil Kumar S, Gopalan N, Hotam Singh C. Keratinloytic actinomycetes isolated from poultry Waste. J Chem Pharm Res 2012;4:4107-11.

21. Kuster E, Williams S. Selection of media for isolation of Streptomycetes. Nature 1964;202:928-9.

22. Ellaiah P, Ramana T, Bapi Raju KVVSN, Sujatha P, Uma sankar A. Investigations on marine actinomycetes from the bay of Bengal near kakinada coast of Andhra Pradesh. Asian J Microbiol Biotechnol Environ Sci 2004;6:53-6.

23. Sujatha $\mathrm{P}$, Swethalatha P. Isolation and screening of novel Streptomyces from sediments of the bay of bengal near srikakulam coast. Int J Curr Pharm Res 2017;9:40-4.

24. Noval JJ, Nickerson WJ. Decomposition of native keratin by Streptomyces fradiae. J Bacteriol 1959;77:251-63.

25. Prakash P, Jayalakshmi SK, Sreeramulu K. Production of keratinase by free and immobilized cells of Bacillus halodurans strain PPKS-2: partial characterization and its application in feather degradation and dehairing of the goatskin. Appl Biochem Biotechnol 2010;160:1909-20.

26. Riffel A, Brandelli A, Bellato CM, Souza GHMF, Eberlin MN, Tavares FCA. Purification and characterization of a keratinolytic metalloprotease from Chryseobacterium sp. kr6. J Biotechnol 2007;128:693-703.

27. Singh C, Parmar RS, Jadon P, Kumar A. Characterization of actinomycetes against phytopathogenic fungi of glycine max (L.). Asian J Pharm Clin Res 2016;9 Suppl 1:216-9.

28. Savitha G Joshi, Tejashwini MM, Revati N, Sridevi R, Roma D. Isolation, identification and characterization of a featherdegrading bacterium. Int J Poult Sci 2007;6:689-93. 